\title{
Freshwater fungi from the River Nile, Egypt
}

\author{
Abdel-Aziz FA
}

Department of Botany and Microbiology, Faculty of Science, Sohag University, Sohag 82524, Egypt

Abdel-Aziz FA 2016 - Freshwater fungi from the River Nile, Egypt. Mycosphere 7(6), 741-756, Doi 10.5943/mycosphere/7/6/4

\begin{abstract}
This study represents the first published data of freshwater fungi from the River Nile in Egypt. Knowledge concerning the geographic distribution of freshwater ascomycetes and their asexual morphs in Egypt and in the Middle East is limited. Ninety-nine taxa representing 42 sexual ascomycetes, 55 asexual taxa and two basidiomycetes were identified from 959 fungal collections recorded from 400 submerged samples. Samples were randomly collected from the River Nile, in Sohag, Egypt in the winter and summer between December 2010 and August 2014. Fifty-eight taxa (22 sexual ascomycetes and 36 asexual taxa) were collected during winter, while 60 taxa (25 sexual ascomycetes, 33 asexual taxa and two basidiomycetes) were collected in summer season. Of the 99 taxa recorded, 50 are new records for Egypt, including five new genera and 30 new species., Three new genera and ten new species were described in previous articles. Fungi recorded from the two seasons were markedly different, with only 19 species common to both winter and summer collections. Asexual fungi dominated the fungal community during the two seasons. Taxonomical placements of 33 species were confirmed by molecular data based on LSU and SSU rDNA genes. Lolia aquatica (14.2\%) was the dominant fungus in both winter and summer collections. Other dominant fungi were: Ceratorhiza sp. (19.5\%) and Limnoperdon sp. (13\%). These two basidiomycetes were the most common taxa in the summer, while they were absent in the winter. Common fungi were Coleophoma emperti (9.2 \%), Zopfiella latipes (8 \%), Discosporium tremuloides $(5.5 \%)$, Trematophoma lignicola $(5.5 \%)$ and Ophioceras commune (5\%). Specious genera recorded from the two seasons were Dictyosporium (6 species), Monodictys-like (3 species), Aniptodera (3 species), Lolia (3 species), Podospora (3 species), Zopfiella (3 species), and two species belong to each of the following genera: Achaetomium, Annulatascus, Lentithecium, Linocarpon, Cirrenalia, Ciliochora, Coleophoma, Colletogloeum, Clohesyomyces, Periconia, Pseudorobillarda and Stagonospora.
\end{abstract}

Key words - asexual fungi - coelomycetes - fungal diversity - fungal ecology - phylogeny

\section{Introduction}

Woody debris and other plant remains enter freshwater through deforestation, irrigation, water runoff during rains and via dams. Filamentous freshwater fungi play a major role in decomposition of plant remains in streams, rivers and lakes and in nutrient recycling (Hyde \& Goh 1998, 1999, Wong et al. 1998, Cai et al. 2003a, b, Jones \& Choeyklin 2008, Raja et al. 2012, Hyde et al. 2016). Shearer (1993) defined freshwater ascomycetes as "all ascomycetes that occur on submerged or partially submerged substrata in aquatic habitats". Freshwater ascomycetes were commonly recorded on woody tissues (Webster 1959, Eaton \& Jones 1971, Hyde \& Goh 1998, 
1999, Wong et al. 1998, Raja et al. 2012), with asexual morphs common on senescent and decayed leaves (Ingold 1942, Goh 1997, Sridhar \& Barlocher 2000), while basidiomycetes are rarely reported on submerged wood in freshwater habitats (Nawawi \& Webster 1982, Marvanova \& Suberkropp 1990, Hyde \& Goh 1999, Sivichai \& Jones 2004, Jones et al. 2014). Freshwater ascomycetes comprise an ecological group belonging to diverse taxonomic groups that increased in number from 288 (Shearer 1993) to 660 (Shearer \& Raja 2016). The current number of asexual morphs of freshwater ascomycetes stands at 573, of which only 14 belong to coelomycetes (Shearer \& Raja 2016). The lignicolous freshwater fungi belong mostly to the classes Dothideomycetes and Sordariomycetes (Hyde et al. 2013, Wijayawardene et al. 2014, Jones et al. 2014, Maharachchikumbura et al. 2015, 2016), a fewer taxa belong to the classes Eurotiomycetes and Orbiliomycetes (Swe et al. 2009, Su et al. 2015), while basidiomycetes and zygomycetes have rarely been encountered on decayed wood in freshwater habitats (Hyde \& Goh, 1999, Jones et al. 2014). Sordariomycetes is the largest group of freshwater ascomycetes and account for 299 out of the 660 taxa (Shearer \& Raja 2016).

Pioneer studies of freshwater ascomycetes have been carried out in lakes in England (Ingold 1954, 1955). In the following years work on freshwater ascomycetes were concentrated in temperate regions (e.g. Jones \& Oliver 1964, Jones \& Eaton 1969, Lamore \& Goos 1978, Shearer \& von Bodman 1983, Shearer \& Crane 1986). In 1993, only 11 taxa were reported from the tropics (Shearer 1993). During the last three decades active research have been carried out on filamentous freshwater fungi in tropical regions of the world especially in Asia-Pacific: Papua New Guinea (Hyde 1994), Australia (Hyde 1996), Brunei (Ho et al. 2001, Hyde 2002), China (Hu et al. 2013), Hong Kong (Goh \& Hyde 1999, Ho et al. 1999, Tsui et al. 2000), Thailand (Hu et al. 2010, Boonyuen et al. 2011, 2012), Peru (Raja et al. 2012). There are no detailed studies in the Middle East in general and only one study of freshwater ascomycetes from Africa (South Africa, Hyde et al. 1998).

Three-quarters of the samples collected during the present study were decayed submerged stems of Phragmites australis which is a tall perennial cosmopolitan grass found on all continents except Antractica (Haslam 1972). It is a colonial plant forming large monospecific stands along the margins of streams, brackish water and in marshes and ditches (Weiss 1979). There have been several studies on the aquatic fungi on P. australis in freshwater (Ingold 1954, 1955, Dudka 1963, Taligoola et al. 1972, Apinis et al. 1972a,b, Luo et al. 2004) and estuarine habitats (Poon \& Hyde 1998, Wong \& Hyde 2001, Ryckegem \& Verbeken 2005, Ryckegem et al. 2007, Abdel-Aziz 2008). In Egypt, a few studies have been carried out on filamentous freshwater fungi on submerged samples from the River Nile and irrigation canals (Abdel-Aziz 2001, 2004, Abdel-Aziz 2011, ElSharouny 2011), however, those previous thesis are M.Sc. and PhD theses and their results are not yet published. This study has been carried out to document the diversity of filamentous freshwater fungi, study their seasonal distribution and taxonomy in the River Nile, Sohag, Egypt.

\section{Materials \& Methods}

\section{Sample examination}

A total of 400 submerged decaying samples (50 decayed wood, 50 decayed date palm rachis and 300 Phragmites australis culm samples) were collected randomly in four collections (100 samples each collected during December 2010, August 2012, December 2012, August 2014) along four kilometer stretch (between $26^{\circ} 34^{\prime} 13.53^{\prime \prime} \mathrm{N}, 31^{\circ} 42^{\prime} 27.72^{\prime \prime} \mathrm{E}$ and $26^{\circ} 32^{\prime} 35.41^{\prime \prime} \mathrm{N}$, $31^{\circ} 42^{\prime} 56.96^{\prime \prime}$ ) of the River Nile bank in Sohag City, Egypt. Samples were returned to the laboratory and incubated in plastic boxes lined with sterilized moist tissue paper at room temperature. Samples were examined periodically for fungal fruiting structures over 3 month incubation. Methods used for the preparation of materials for light microscopy have been reported by Jones and Hyde (1988). Permanent slides and herbarium materials of the fungi recorded were deposited in the author's herbarium and can be examined on request. The following data were calculated for the study site: 
Table 1 Frequency of occurrence of taxa recorded at the study :

\begin{tabular}{|c|c|c|c|c|}
\hline Fungi & winter & summer & Total & Host \\
\hline \multicolumn{5}{|l|}{ Ascomycota } \\
\hline 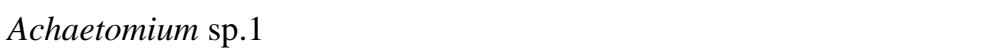 & 2 & - & 1 & Ph. \\
\hline Achaetomium sp.2 & - & 4 & 2 & D., Ph. \\
\hline \# **Angustospora nilensis Abdel-Aziz gen. et sp. nov. & 1 & - & 0.5 & D. \\
\hline Aniptodera aquadulcis (S.Y. Hsieh, H.S. Chang \& E.B.G. Jones) & 2 & - & 1 & D. \\
\hline \multicolumn{5}{|l|}{ J. Campb., J.L. Anderson \& Shearer } \\
\hline Aniptodera chesapeakensis Shearer \& M.A. Mill & 2 & - & 1 & D. \\
\hline Aniptodera fusiformis Shearer & 2.5 & - & 1.2 & D. \\
\hline \#**Annulatascus nilensis Abdel-Wahab \& Abdel-Aziz & 2.5 & - & 1.2 & $\mathrm{Ph}$. \\
\hline *Annulatascus sp. & - & 1.5 & 0.7 & $\mathrm{Ph}$. \\
\hline *Aquaticola sp. & - & 1 & 0.5 & $\mathrm{Ph}$. \\
\hline Chaetomium sp. & - & 2 & 1 & Ph. \\
\hline \#**Helicascus aegyptiacus Abdel-Wahab \& Abdel-Aziz & - & 6 & 3 & D., Ph. \\
\hline Jahnula aquatica (Kirschst.) Kirschst & 3 & - & 1.5 & D. \\
\hline *Lentithecium cangshanense Z.L. Luo, X.J. Su \& Hyde (Microthelia) & 3 & - & 1.5 & $\mathrm{Ph}$. \\
\hline \# **Lentithecium unicellularis Abdel-Aziz sp. nov. & - & 2.5 & 1.2 & D., Ph. \\
\hline *Leptosphaeria sp. & 1.5 & 4 & 2.7 & D., Ph. \\
\hline *Lindra sp. & 1 & - & 0.5 & $\mathrm{Ph}$. \\
\hline *Linocarpon verminosum (Mont.) K.D. Hyde & 2.5 & - & 1.2 & D., Ph. \\
\hline *Linocarpon sp. & 1.5 & - & 0.7 & D., P. \\
\hline \# **Lolia aquatica Abdel-Aziz \& Abdel-Wahab gen. et sp. nov. & 13.5 & 15 & 14.2 & D., $\mathrm{Ph}$. \\
\hline \#** Lolia dictyospora Abdel-Aziz sp. nov. & - & 1 & 0.5 & $\mathrm{Ph}$. \\
\hline \#**Lolia sp. (Coelomycete 128) & - & 6.5 & 3.2 & $\mathrm{Ph}$. \\
\hline Lulworthia sp. & 1 & - & 0.5 & D., Ph. \\
\hline *Massarina sp. & 1 & - & 0.5 & $\mathrm{Ph}$. \\
\hline \#**Murispora sp. & 1 & - & 0.5 & $\mathrm{Ph}$. \\
\hline Nais aquatica K.D. Hyde & - & 2.5 & 1.2 & $\mathrm{Ph}$. \\
\hline *Nectria sp. & - & 3.5 & 1.7 & $\mathrm{Ph}$. \\
\hline \# Ophioceras commune Shearer, J.L. Crane \& W. Chen & 6 & 4 & 5 & Ph. \\
\hline *Otthia sp. & 2.5 & - & 1.2 & D. \\
\hline *Orbillia $\mathrm{sp}$ & - & 3 & 1.5 & $\mathrm{Ph}$. \\
\hline Pleospora vagans var. aconiti Gawande \& D.K. Agarwal & - & 3 & 1.5 & Ph. \\
\hline \#**Pleurotheciella sp. & - & 2.5 & 1.2 & D. \\
\hline *Podospora carpinicola Mouch & - & 3.5 & 1.7 & D., Ph. \\
\hline \#**Podospora sp. 1 & - & 2.5 & 1.2 & D. \\
\hline \#**Podospora sp. 2 & - & 1.5 & 0.7 & $\mathrm{Ph}$. \\
\hline \#**Pseudoastrosphaeriella sp. & 2.5 & - & 1.2 & Ph. \\
\hline \# *Pseudohalonectria lignicola Minoura \& Muroi & 1.5 & 4.5 & 3 & $\mathrm{Ph}$. \\
\hline *Thielavia antarctica Stchigel \& Guarro & 1.5 & - & 0.7 & $\mathrm{Ph}$. \\
\hline Tirispora unicaudata E.B.G. Jones \& Vrijmoed & - & 2 & 1 & $\mathrm{Ph}$. \\
\hline \#**Westerdykella sp. & - & 4 & 2 & $\mathrm{Ph}$. \\
\hline Zopfiella leucotricha (Speg.) Malloch \& Cain & - & 5 & 2.5 & D., $\mathrm{Ph}$. \\
\hline Zopfiella latipes (N. Lundq.) Malloch \& Cain & 4 & 12 & 8 & D., $\mathrm{Ph}$. \\
\hline *Zopfiella sp. & - & 1.5 & 0.7 & D. \\
\hline
\end{tabular}




\begin{tabular}{|c|c|c|c|c|}
\hline \multicolumn{5}{|l|}{$\underline{\text { Asexual fungi }}$} \\
\hline \# **Acroclymma sp. & - & 1.5 & 0.7 & D. \\
\hline Alveophoma caballeroi Alcalde & 2.5 & 4.5 & 3.5 & P. \\
\hline *Aoria amphistroma Cif & 3 & 5.5 & 4.2 & P. \\
\hline *Ceuthospora heteromelicola Nag Raj & 4 & - & 2 & D. \\
\hline *Chaetasbolisia erysiphoides Griffon \& Maubl & 3.5 & 2.5 & 3 & D., P. \\
\hline *Chaetosphaeronema hispidulum (Corda) Moesz & 2.5 & 4.5 & 3.5 & P. \\
\hline \#**Cheirosporium vesiculare Abdel-Aziz sp. nov. & - & 1.5 & 0.7 & D. \\
\hline *Ciliochora longiseta (Racib.) Höhn & 2.5 & - & 1.2 & P. \\
\hline *Ciliochora sp. & 1 & - & 0.5 & $\mathrm{Ph}$. \\
\hline *Cirrenalia sp.1 & 2 & - & 1 & D., $\mathrm{Ph}$. \\
\hline *Cirrenalia sp.2 & 3 & - & 1.5 & $\mathrm{Ph}$. \\
\hline *Clohesyomyces aquaticus K.D. Hyde & - & 3 & 1.5 & $\mathrm{Ph}$. \\
\hline \#**Clohesyomyces sp. & - & 2.5 & 1.2 & $\mathrm{Ph}$. \\
\hline *Coleophoma empetri (Rostr.) Petr & 5 & 13.5 & 9.2 & P., Ph. \\
\hline *Coleophoma oleae (DC.) Petr. \& Syd & 2 & 5 & 3.5 & D., $\mathrm{Ph}$. \\
\hline *Colletogloeum obtusum B. Sutton & - & 3 & 1.5 & Ph. \\
\hline *Colletogloeum olacis B. Sutton & - & 2 & 1 & $\mathrm{Ph}$. \\
\hline *Crandallia juncicola Ellis \& Sacc. & 3.5 & - & 1.7 & D., $\mathrm{Ph}$. \\
\hline Dialaceniopsis landolphiae Bat. & 1.5 & 2.5 & 2 & D., $\mathrm{Ph}$. \\
\hline \# **Dictyosporella aquatica Abdel-Aziz gen. et sp. nov. & - & 9 & 4.5 & $\mathrm{Ph}$. \\
\hline \# **Dictyosporium aquaticum Abdel-Aziz sp. nov. & - & 5.5 & 2.7 & P. \\
\hline *Dictyosporium australiense B. Sutton & 6 & - & 3 & D., P. \\
\hline *Dictyosporium bulbosum Tzean \& J.L. Chen & 5 & - & 2.5 & D., P. \\
\hline Dictyosporium cocophylum Bat. & 8 & - & 4 & D. \\
\hline Dictyosporium digitatum J.L. Chen, C.H. Hwang \& Tzean & 7 & - & 3.5 & P. \\
\hline \# **Dictyosporium palmae Abdel-Aziz sp. nov. & - & 4 & 2 & P. \\
\hline *Diplodina microsperma B. Sutton & 6 & 2.5 & 4.2 & P., Ph. \\
\hline *Diplozythiella bambusina Died. & 2 & - & 1 & D., P. \\
\hline *Discosporium tremuloides (Ellis \& Everh.) B. Sutton & 6.5 & 4.5 & 5.5 & P., Ph. \\
\hline Hapalosphaeria deformans (Syd. \& P. Syd.) Syd. & 2 & - & 1 & P. \\
\hline \#**Koorchalomella sp. & 3 & - & 1.5 & $\mathrm{Ph}$. \\
\hline *Megalodochium elaeidis (Beeli) Deighton & 1.5 & - & 0.7 & D. \\
\hline \# **Myrothecium sp. & - & 2.5 & 1.2 & P. \\
\hline \# **Monodictys sp. 1 (MD1308) & 1.5 & 4 & 2.7 & $\mathrm{Ph}$. \\
\hline \# **Monodictys sp. 2 (MD1309) & 2 & 10 & 6 & $\mathrm{Ph}$. \\
\hline \# **Monodictys sp. 3 (MD1314) & 1 & 8 & 5 & D., $\mathrm{Ph}$. \\
\hline *Nigrospora sp. & - & 2 & 1 & $\mathrm{Ph}$. \\
\hline *Periconia laminella E.W. Mason \& M.B. Ellis & 2 & - & 1 & $\mathrm{Ph}$. \\
\hline Periconia prolifica Anastasiou & 2.5 & - & 1.2 & D., Ph. \\
\hline *Pesotum $\mathrm{sp}$ & 2 & - & 1 & $\mathrm{Ph}$. \\
\hline *Phacidiella asperulina (Bubák) B. Sutton & 4 & - & 2 & $\mathrm{Ph}$. \\
\hline *Phyllosticta sp. & 1.5 & - & 0.7 & $\mathrm{Ph}$. \\
\hline \#**Pseudorobillarda sp. 1 & 4.5 & 4 & 4.2 & $\mathrm{Ph}$. \\
\hline
\end{tabular}


Table 1 continued

\#**Pseudorobillarda $\mathrm{sp}$. 2

\#*Sporoschisma hemipsila (Berk. \& Broome) Zelski, A.N. Mill. \&

Shearer

*Stagonospora anglica Cunnell

*Stagonospora caricis (Oudem.) Sacc.

*Topospora uberiformis (Kunze) Fr.

Torula herbarum (Pers.) Link

*Trematophoma lignicola Petr.

\#**Tricocladium sp. (algae)

*Unknown coelomycete MD6041

*Unknown coelomycete MD6042

*Unknown coelomycete MD6043

\#** Unknown orange conidia MD6055

\section{Basidiomycota}

\begin{tabular}{|c|c|c|c|c|}
\hline \#**Ceratorhiza $\mathrm{sp}$ & - & 39 & 19.5 & D., Ph. \\
\hline \# **Limnoperdon $\mathrm{sp}$ & - & 26 & 13 & D., Ph. \\
\hline Number of samples collected & 200 & 200 & 400 & \\
\hline Total number of fungal taxa & 58 & 60 & 99 & \\
\hline Number of Ascomycetes & 22 & 25 & 42 & \\
\hline Number of Sordariomycetes & 13 & 17 & 27 & \\
\hline Number of Dothideomycetes & 9 & 8 & 15 & \\
\hline Number of Asexual fungi & 36 & 33 & 55 & \\
\hline Number of Coeleomycetes & 22 & 20 & 31 & \\
\hline Number of Hyphomycetes & 14 & 13 & 24 & \\
\hline Number of Basidiomycetes & - & 2 & 2 & \\
\hline Total number of fungal collections & 355 & 604 & 959 & \\
\hline Number of fungi per wood sample & 1.78 & 3.02 & 2.4 & \\
\hline
\end{tabular}

* New record

** New species

\# supported by molecular data

$\mathrm{D}=$ Dicot wood

$\mathrm{P}=$ Date Palm rachis

$\mathrm{Ph}=$ Phragmites australis

Percentage occurrence of each fungus $=\underline{\text { Number of collections of the fungus }} \times 100$

\section{Number of samples collected}

Number of fungi per sample $=\underline{\text { Total number of fungal collections }}$

Number of samples collected

Jaccard and Sorenson similarity indices for the mycota of the two seasons were calculated according to the formulae:

Jaccard similarity index $(C \mathrm{j})=\mathrm{j} /(\mathrm{a}+\mathrm{b}-\mathrm{j})$

Sorenson similarity index $(\mathrm{C} \mathrm{s})=2 \mathrm{j} /(\mathrm{a}+\mathrm{b})$

Where $\mathrm{j}=$ is the number of species common to both seasons, and $\mathrm{a}=$ the number of species in site $\mathrm{A}$, with $\mathrm{b}=$ the number of species in site $\mathrm{B}$. For both indices, values of unity indicate cases of complete similarity, and a value of zero indicates $100 \%$ dissimilarity.

Menhinick's diversity indices were calculated for the summer and winter collections according to the formula:

DMn (Menhinick's diversity index $)=\mathrm{S} / \sqrt{ } \mathrm{N}$ 
Where $\mathbf{S}$ is the total number of species and $\mathbf{N}$ is the total number of fungal collections from the site. Photographs were taken using an Olympus BX51 differential interference contrast light microscope (Olympus, Tokyo, Japan) and Optika view version 7.3.1.7 (Italy) digital imaging system. Single spore cultures of the recorded fungi were obtained according the methods described by AbdelWahab et al. (2016).

\section{Results}

Ninety-nine taxa representing 42 sexual ascomycetes, 55 asexual taxa and two basidiomycetes were identified from 959 fungal collections recorded from 400 submerged samples. These were randomly collected from the River Nile, Sohag, Egypt in the winter and summer between December 2010 and August 2014. Of the 99 taxa recorded, 50 are new records for Egypt including five new genera and 30 new species, of which three new genera and ten new species were described in previous articles namely Lolia aquatica Abdel-Aziz \& Abdel-Wahab (Abdel-Aziz \& Abdel-Wahab 2010), Annulatascus nilensis Abdel-Wahab \& Abdel-Aziz (Abdel-Wahab et al. 2011), Helicascus aegyptiacus Abdel-Wahab \& Abdel-Aziz (Zhang et al. 2013), Dictyosporium aquaticum Abdel-Aziz (Liu et al. 2015), Dictyosporella aquatica Abdel-Aziz (Ariyawansa et al. 2015), Angustospora nilensis Abdel-Aziz (Li et al. 2016), Lolia dictyospora Abdel-Aziz (AbdelAziz 2016a), Cheirosporium vesiculare Abdel-Aziz and Dictyosporium palmae Abdel-Aziz (AbdelAziz 2016b) and Lentithecium unicellularis Abdel-Aziz (Hyde et al. 2016). Fifty-eight taxa (22 sexual ascomycetes and 36 asexual taxa) were collected during winter season, while 60 taxa (25 sexual ascomycetes, 33 asexual taxa and two basidiomycetes) were collected in summer. Fungal communities in the two seasons were markedly different, Jaccard and Sorenson similarity indices were 0.2 and 0.33 respectively which means that the similarity between the mycota at the two seasons was very low, with only 19 taxa (5 sexual ascomycetes and 14 asexual taxa) recorded consistently over the two seasons. This reflects different fungal community composition from one season to another. Menhinick's diversity indices were 3.08 and 2.44 for winter and summer collections, respectively, which indicates a higher fungal diversity during winter season. Asexual taxa dominated the fungal community in both seasons. Sexual ascomycetes (42 taxa) was the dominant fungal group followed asexual morphs. Taxonomical placements of 33 species were confirmed by molecular data based on LSU and SSU rDNA sequence data. Lolia aquatica (with $14.2 \%$ total frequency of occurrence) was the dominant taxon from both winter and summer collections. Other dominant taxa were: Ceratorhiza sp. (19.5\%) and Limnoperdon sp. (13\%) (Fig. 1). These basidiomycetes were the most common fungi in summer season, while they were absent in winter. Common taxa included Coleophoma emperti (9.2 \%), Zopfiella latipes (8 \%), Discosporium tremuloides (5.5\%), Trematophoma lignicola $(5.5 \%)$ and Ophioceras commune (5 $\%)$. Specious genera recorded from the two seasons were Dictyosporium (6 species), Monodictyslike (3 species), Aniptodera (3 species), Lolia (3 species), Podospora (3 species), Zopfiella (3 species) and two taxa belonged to each of the following genera: Achaetomium, Annulatascus, Lentithecium, Linocarpon, Cirrenalia, Ciliochora, Coleophoma, Colletogloeum, Clohesyomyces, Periconia, Pseudorobillarda and Stagonospora (Table1). Of the 42 sexual ascomycetes reported in this study, 27 belong to Sordariomycetes and 15 to Dothideomycetes (Figs 2-4).

\section{Fungi recorded in the winter season}

Fifty eight taxa (22 sexual ascomycetes and 36 aexual taxa) were identified from 355 fungal collection from 200 samples with an average of 1.77 species identified on each sample. The ratio of asexual taxa /ascomycetous taxa was 1.63. Frequency of occurrence of all taxa ranged from 1 to 13.5\%. Lolia aquatica was the only frequent species (13.5\%). Dictyosporium cocophylum (8\%), Dictyosporium digitatum (7\%), Discosporium tremuloides (6.5\%), Dictyosporium australiense (6\%), Diplodina microsperma (6\%), Ophioceras commune (6\%), Stagonospora anglica (5.5\%), Dictyosporium bulbosum (5\%) and Coleophoma empetri (5\%) were occasional taxa, while 48 were recorded as rare taxa and are listed in table (1). 


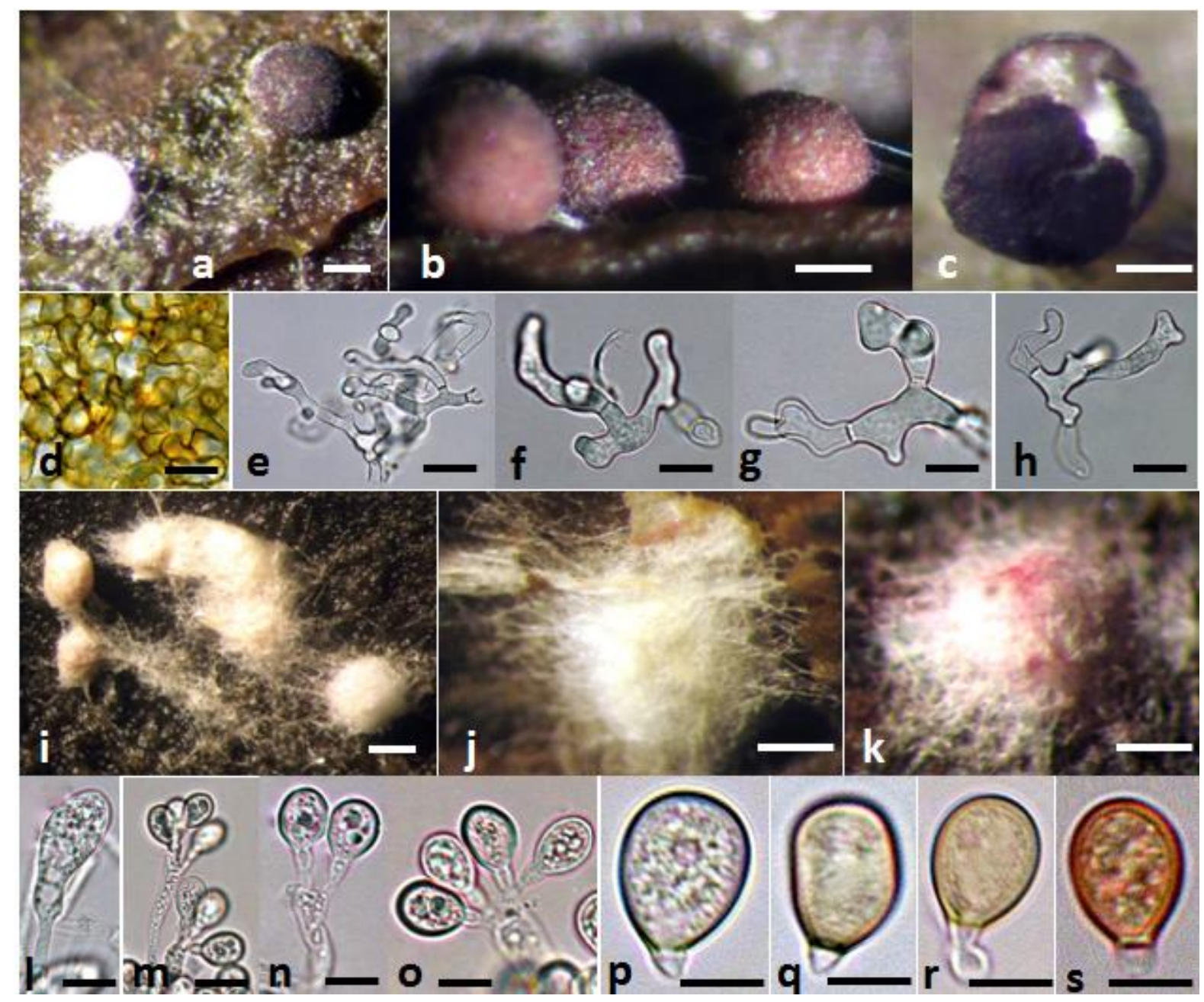

Fig. 1 - a-h. Ceratorhiza sp. a-c Sclerotia at different stages of maturation on wood. d,c. Surface view of the perdium. $\mathbf{e}-\mathbf{h}$. Branched and septate mycelia that found inside sclerotia. $\mathbf{i}-\mathbf{s}$. Limnoperdon sp. $\mathbf{i}-\mathbf{k}$. Basidiocarps on wood at different stages of development. l. Young basidium. $\mathbf{m}-\mathbf{0}$. Basidia and basidiospores. p-s. Variously shaped basidiospores. Scale bars: $\mathrm{a}-\mathrm{c}, \mathrm{i}-\mathrm{k}=200$ $\mu \mathrm{m}, \mathrm{d}-\mathrm{h}, \mathrm{l}-\mathrm{s}=10 \mu \mathrm{m}$.

\section{Fungi recorded in the summer season}

Sixty taxa (25 sexual ascomycetes, 33 asexual taxa and two basidiomycetes) were identified from 604 fungal collections from 200 samples with an average of 3 species identified on each sample. The ratio of asexual taxa/sexual taxa was 1.22. Frequency of occurrence of all taxa ranged from 1 to 39\%. Ceratorhiza sp. (39\%) and Limnoperdon sp. (26\%) were very frequent species and were recorded only in the summer season. Lolia aquatica (15\%), Coleophoma empetri (13.5\%) and Zopfiella latipes (12\%) were frequent species and were recorded in the winter and summer. Eight species were occasional species, while 46 taxa were rare and are listed in Table 1.

\section{Discussion}

This study extends our knowledge on freshwater fungi in Egypt. A few studies have been carried out on freshwater fungi in Egypt and these include Abdel-Aziz (2001) who recorded 64 taxa from decayed wood samples collected from River Nile (Sohag, Qena and Aswan) and on wood blocks exposed at River Nile at Sohag governorate, of the 64 fungi recorded in this study only seven species were recorded in the present study. Abdel-Aziz (2004) recorded 116 (56 asexual ascomycetes and 60 asexual taxa) taxa from 668 samples collected from River Nile, irrigation canals and a high dam lake (unpublished data), of the 116 fungi recorded in this study, only 15 were recorded in this study. 


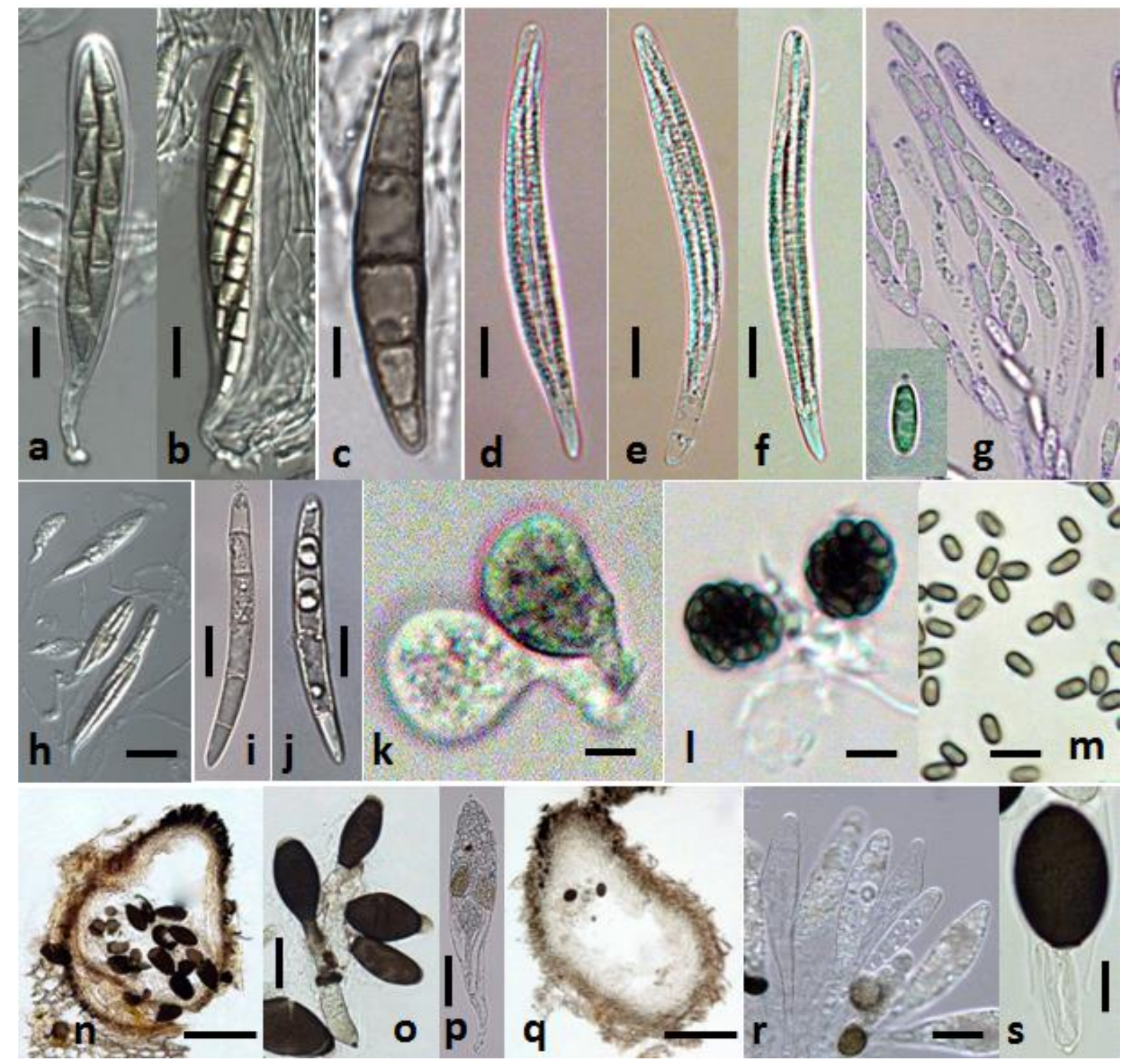

Fig. 2 - a-c. Pseudoastrosphaeriella sp. a-b. Asci. c. Ascospores. d-f. Asci of Ophioceras commune. g. Asci and ascospores (stained in blue) of Aquaticola sp. h-j. Pseudohalonectria lignicola. h. Asci. i-j. Ascospores. k-m. Westerdykella sp. $\mathbf{k}-\mathbf{l}$. Asci at different stages of maturity. $\mathrm{m}$ ascospores. n-p. Podospora sp.1 n. Vertical section through ascomata. o. Ascospores. p. Immature ascus. q-s. Podospora sp. 2 q. Vertical section through ascomata. $\mathbf{r}$. Immature asci. $\mathbf{s}$ Ascospore. Scale bars: $\mathrm{a}-\mathrm{b}, \mathrm{h}=20 \mu \mathrm{m}, \mathrm{c}-\mathrm{g}, \mathrm{i}-\mathrm{m}=10 \mu \mathrm{m}, \mathrm{n}, \mathrm{q}=120 \mu \mathrm{m}, \mathrm{o}, \mathrm{s}=10 \mu \mathrm{m}, \mathrm{p}, \mathrm{r}=30 \mu \mathrm{m}$.

In the present study, higher numbers of asexual taxa than sexual fungi was recorded from the two seasons (55 asexual fungi vs. 42 ascomycetes and 2 basidiomycetes). The ratios of asexual to sexual taxa were 1.63 in winter season and 1.22 in summer season. These results agree with those of Abdel-Aziz (2008) who recorded 34 asexual fungi and 26 ascomycetes from Lake Manzala (brackish water). Tsui et al. (2000) reported similar results from various freshwater habitats in Hong Kong namely: Tung Chung River (2.2 asexual: 1 sexual taxa), Hang Cho Shui and Tai Po Kau Forest Stream (2:1). Similar results were recorded from different parts of the world: Palmiet river, South Africa (1.1: 1) (Hyde et al. 1998), Lake Barrine, Queensland, Australia (1.5:1) (Hyde \& Goh 1998) and Brunei (1.4: 1) (Ho et al. 2001). The reasons for the variation in dominance of asexual fungi over ascomycetes are unknown. Only one species of discomycete, Orbillia sp., was recorded in the present study, however, the occurrence of discomycetes on wood submerged in tropical and subtropical rivers is rare (Hyde et al. 2016). 


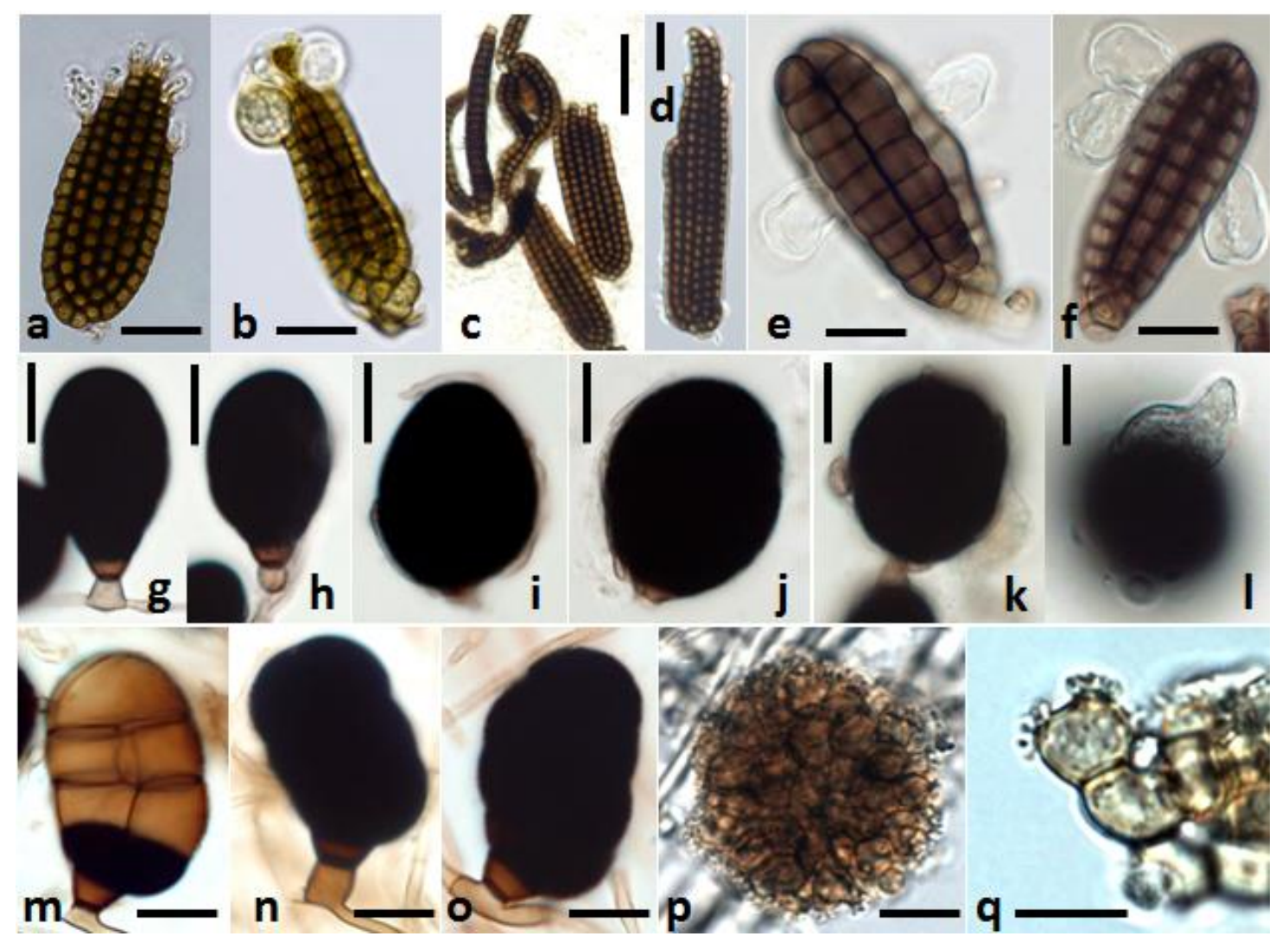

Fig. 3 - a-b Conidia of Dictyosporium aquaticum. c-d. Conidia of Dictyosporium palmae. e-f. Conidia of Cheirosporium vesiculare. $\mathbf{g}-\mathbf{i}$. Conidia of Monodictys sp.1. $\mathbf{j}-\mathbf{l}$. Conidia of Monodictys sp.2. $\mathrm{m}-\mathrm{o}$ Conidia of Monodictys sp.3. p-q. Unknown orange conidia. Scale bars: $\mathrm{a}-\mathrm{b}, \mathrm{g}-\mathrm{q}=10$ $\mu \mathrm{m}, \mathrm{c}=30 \mu \mathrm{m}$.

Two new basidiomycetes species namely: Ceratorhiza and Limnoperdon were the most frequent fungi in summer. Jones et al. (2014) listed 115 Basidiomycetes from freshwater habitats, of which nine species were recorded from wood. Eleven Ceratorhiza species are currently described (Index Fungorum 2016). Species of Ceratorhiza are associated with roots and plant pathogens and the presence of species in freshwater habitats in unusual. The fungus produce white fluffy, superfecial scelrotia that turn to brown to reddish dark-brown with age and contain white mass of branched and septate mycelia (Fig. 1). Limnoperdon species recorded in the present study represent the second species in the genus. Limnoperdon incarnatum G.A. Escobar was described from submerged hardwood twigs from a freshwater marsh on the shore of Union lake, Seattle, Washington, USA, and referred to the Gasteromycetes (Escobar et al. 1976). Subsequently it has been reported from wood blocks submerged in brackish water (Tubaki 1977) and paddy-field soil (Ito \& Yokoyama 1979).

Thirty-one coelomycetes were recorded in the present and this a high number of this fungal group compared to recorded results from different parts of the world. Only 14 species of coelomycetes were recorded worldwide (Shearer \& Raja 2016). Thirty new fungi were recorded during the present study. This high percentage of new species might be explained by: (1) a few extensive studies have been carried out on filamentous freshwater fungi in Egypt. (2) Wood samples were exposed to direct sun light, high temperatures and low humidity level, thus samples and fungal material exposed to desiccation daily. Such condition creates a unique mycota different from those recorded from subtropical, tropical or temperate sites. Also fungal communities in temperate and tropical streams rarely overlap (Hyde \& Goh 1999). Besides the water temperature, the biodiversity and communities of lignicolous freshwater fungi are affected by the structure and diversity of the riparian vegetation and the quality of stream water (Tsui et al. 2001, Vijaykrishna \& Hyde 2006). 


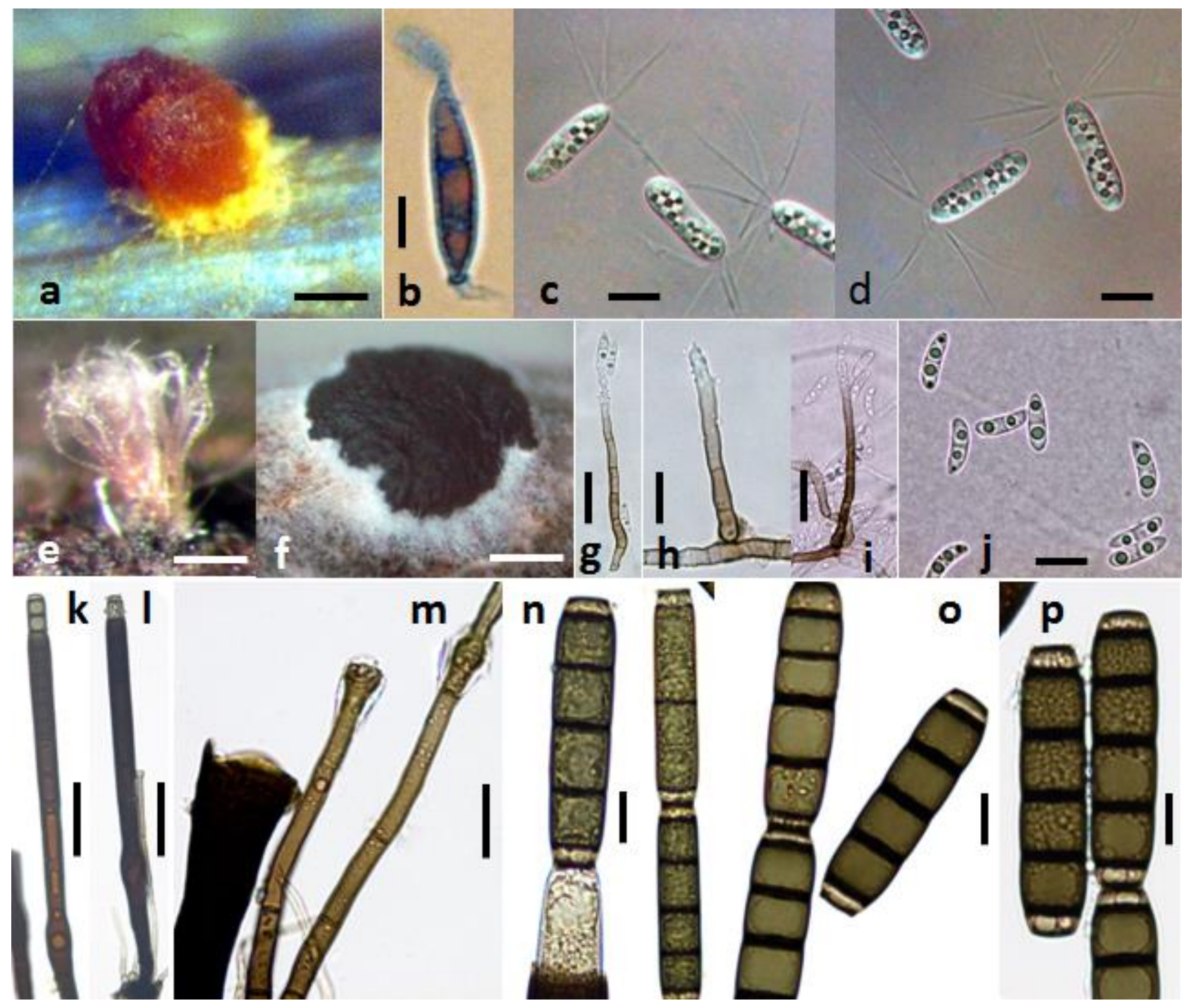

Fig. 4 - a-b. Koorchalomella sp. a. Sporodochium on wood. b. Conidium with polar mucoid funnel-shaped appendages. c-d. Conidia of Pseudorobillarda sp.1. e. Sporodochium of Murispora sp. f. Sporodochium of Myrothecium sp. g-j. Pleurotheciella sp. g-i. Conidiophores. j. Conidia. kp. Sporoschisma hemipsila. $\mathbf{k}-\mathbf{n}$. Conidiophores and conidiogenous cells. $\mathbf{o}-\mathbf{p}$. Conidia. Scale bars: $\mathrm{a}, \mathrm{e}-\mathrm{f}=150 \mu \mathrm{m}, \mathrm{b}-\mathrm{d}, \mathrm{g}-\mathrm{j}, \mathrm{n}-\mathrm{p}=10 \mu \mathrm{m}, \mathrm{k}-\mathrm{l}=150 \mu \mathrm{m}, \mathrm{m}=15 \mu \mathrm{m}$.

Of the 42 ascomycetes reported in this study, 27 belong to Sordariomycetes and 15 to Dothideomycetes. Higher percentages of the two classes were recorded from freshwater habitats around the globe (Hyde et al. 2016). Sordariomycetes represented around 60\% of total ascomycetes in China ( $\mathrm{Hu}$ et al. 2013) and 45\% worldwide (Shearer \& Raja 2016), while Dothideomycetes comprised around 34\% worldwide (Shearer \& Raja 2016). Dominance of Sordariomycetes and Dothideomycetes in freshwater might be explained by their abilities to produce superficial to immersed ascomata with gelatinous centrum, active ascospores dispersal and their ascospores equipped with elaborated appendages or gelatinous sheaths (Hyde and Goh 2003).

\section{Fungi on Phragmites australis}

During the present study, sixty-nine taxa representing 32 ascomycetes, 35 asexual taxa and two basidiomycetes were identified from 300 submerged samples of $P$. australis during the two seasons. Shearer (1993) listed 34 freshwater ascomycetes from submerged portions of $P$. australis and that increased to 50 (47 ascomycetes and 3 asexual fungi) (Shearer \& Raja 2016). Eighty-one taxa were recorded from $P$. australis in temperate regions (England) (Apinis et al. 1972a,b, Taligoola et al. 1972), of which only 23 species were listed by Shearer (1993) as freshwater fungi. 
Luo et al. (2004) identified 21 fungi (8 ascomycetes and 13 asexual taxa) from 100 samples of $P$. australis collected from Lake Dianchi, a heavily polluted lake in Yunnan, China with only two species were common to this study namely: Pseudohalonecteria lignicola and Sporoschisma hemipsila. Abdel-Aziz (2008) identified 60 taxa (26 ascomycetes and 34 asexual taxa) from 300 decayed samples of $P$. australis collected from Lake Manzala, a brackish lake in northern Egypt. Eight fungi were common to this study and Lake Manzala namely: Aniptodera aquadulcis, A. fusiformis, Nais aquatica, Zopfiella leucotricha, Alveophoma caballerai, Dialaceniopsis landophiae, Hapalosphaeria deformans and Periconia prolifica (Table 1).

\section{Acknowledgements}

This project is supported by Department of Botany and Microbiology, Faculty of Science, Sohag University. Dr. Shaun Pennycook is thanked for checking Latin names.

\section{References}

Abdel-Aziz AE. 2011 - Taxonomical studies on some selected genera of aquatic fungi in Egypt. M. Sc. Thesis, Sohag University, Egypt, 166.

Abdel-Aziz FA. 2001 - Biodiversity of higher freshwater fungi in the Nile. M. Sc. Thesis, South Valley University, Egypt, 125.

Abdel-Aziz FA. 2004 - Biodiversity of aquatic fungi from the River Nile to the Sea. Ph. D. thesis, South Valley University, Egypt, 223.

Abdel-Aziz FA. 2008- Diversity of aquatic fungi on Phragmites australis at Lake Manzala, Egypt. Sydowia 60, 1-14.

Abdel-Aziz FA. 2016a - The genus Lolia from freshwater habitats in Egypt with one new species. Phytotaxa 267, 279-288. http://dx.doi.org/10.11646/phytotaxa.267.4.4

Abdel-Aziz FA 2016b - Two new cheirosporous asexual taxa (Dictyosporiaceae, Pleosporales, Dothideomycetes) from freshwater habitats in Egypt. Mycosphere 7(4), 448-457, http://doi 10.5943/mycosphere/7/4/5

Abdel-Aziz FA, Abdel-Wahab MA. 2010 - Lolia aquatica gen. et sp. nov. (Lindgomycetaceae, Pleosporales), a new coelomycete from freshwater habitats in Egypt. Mycotaxon 114, 3342. http://dx.doi.org/10.5248/114.33

Abdel-Wahab MA, Abdel-Aziz FA, Mohamed SS, Abdel-Aziz AE, 2011. Annulatascus nilensis sp. nov., a new freshwater ascomycete from the River Nile, Egypt. IMA Fungus 2, 1-6. http://dx.doi: 10.5598/imafungus.2011.02.01.01

Abdel-Wahab MA, Bahkali AH, Jones EBG, Elgorban AM, Abdel-Aziz FA, Hodhod MS, AlHebshi MO. 2016 - Two new species of Kallichroma (Bionectriaceae, Hypocreales) from Saudi Arabian mangroves. Phytotaxa 66-74. http://dx.doi.org/10.11646/phytotaxa.260.1.7

Apinis AE, Chesters CGC, Taligoola HK. 1972a - Colonisation of Phragmites communis leaves by fungi. Nova Hedwigia 23, 113-124.

Apinis AE, Chesters CGC, Taligoola HK. 1972b - Microfungi colonizing submerged standing culms of Phragmites communis Trin. Nova Hedwigia 23: 473-480.

Ariyawansa HA, Hyde KD, Jayasiri SC, Buyck B, Chethana KWT, Cui Y-Y, Dai DQ, Dai YC, Dinushani A, Daranagama DA, Jayawardena RS, Lücking R, Ghobad-Nejhad M, Niskanen T, Thambugala KM, Voigt K, Zhao RL, Boonmee S, Bahkali AH, Chen J, Cui BK, Dayarathne MC, Dissanayake AJ, Ekanayaka AH, Hashimoto A, Hongsanan S, Jones EBG, Larsson E, Lewis D, Li WJ, Li Q-R, Liu JK, Luo ZL, Maharachchikumbura SSN, Mapook A, McKenzie EHC, Norphanphoun C, Pang KL, Perera RH, Phookamsak R, Phukhamsakda C, Randrianjohany E, Senanayake IC, Singtripop C, Shang Q, Tanaka K, Tian Q, Tian CM, Tibpromma S, Verbeken A, Abdel-Wahab MA, Wanasinghe D, Wijayawardene NN, Zhang JF, Zhang H, Abdel-Aziz FA, Wedin M, Westberg M, Ammirati JF, Bulgakov TS, Lima DX, Callaghan TM, Callac P, Chang CH, Coca LF, Dal-Forno M, Dollhofer V, Fliegerová 
K, Greiner K, Griffith GW, Ho HM, Hofstetter V, Jeewon R, Kang JC, Wen TC, Kirk PM, Kytövuori I, Lawrey JD, Xing J, Li H, Liu ZY, Liu XZ, Liimatainen K, Thorsten Lumbsch H, Matsumura M, Moncada B, Nuankaew S, Parnmen S, Santiago ALCMDA, Sommai S, Song Y, de Souza CAF, de Souza-Motta CM, Su HY, Suetrong S, Wang Y, Fong WS, Yuan HS, Zhou LW, Réblová M, Fournier J, Camporesi E, Luangsa-ard JJ, Tasanathai K, Khonsanit A, Thanakitpipattana D, Somrithipol S, Diederich P, Millanes AM, Common RS, Stadler M, Yan JY, Li XH, Lee HW, Nguyen TTT, Lee HB, Battistin E, Marsico O, Vizzini A, Vila J, Ercole E, Eberhardt U, Simonini G, Wen HA, Chen XH, Miettinen O, Spirin V, Hernawati. 2015 - Fungal diversity notes 111-252-taxonomic and phylogenetic contributions to fungal taxa. Fungal Diversity 75, 27-274. http://dx.doi.org/10.1007/s13225015-0355-4

Boonyuen N, Chuassharonnachai C, Suetrong S, Sriindrasuthdhi V, Sivi chai S, Jones EBG. 2011 Savoryellales (Hypocreomycetideae, Sordariomycetes): a novel lineage of aquatic ascomycetes inferred from multiple- gene phylogenies of the genera Ascotaiwania dia and Savoryella. Mycologia; 103, 1351-1371. http://dx.doi.org/10.3852/11-102

Boonyuen N, Sir-Indrasutdhi V, Suetrong S, Sivichai S, Jones EBG. 2012 - Annulatascus aquatorba sp. Nov., alignicolous freshwater ascomycete from sired horn peat swamp forest, Narathiwat, Thailand. Mycologia 104, 746-757. http://dx.doi.org/10.3852/11-238

Cai L, Zhang K, McKenzie EHC, Hyde KD. 2003a - New species of Dictyosporium and Digitodesmium from submerged wood in Yunnan, China. Sydowia 55, 129-135.

Cai L, Zhang K, McKenzie EHC, Lumyong S, Hyde KD. 2003b - New species of Canalisporium and Dictyosporium from China and a note on the differences between these genera. Cryptogamie Mycologie 24, 3-11.

Dudka IO. 1963 - Data on the flora of aquatic fungi of the Ukrainian SSR. II. Aquatic Hyphomycetes of Kiev Polessye. Ukrainskyi Botanichnyi Zhurnal 20, 86-93.

Eaton RA, Jones EBG. 1971 - The biodeterioration of timber in water-cooling towers I. Fungal Ecology and the decay of wood at connah's Quay and Ince. Material and Organismen 6, 8192.

El-Sharouny MA. 2011 - Ecology and Mycoflora of Phragmites australis in Upper Egypt. M. Sc. Thesis, Sohag University, Egypt, 203.

Escobar GA, McCabe DE, Harpel CW. 1976 - Limnoperdon, a floating gasteromycete isolated frommarshes. Mycologia 87, 874-880. http://dx.doi.org/10.2307/3758803

Goh TK. 1997 - Tropical freshwater hyphomycetes. in: Biodiversity of tropical microfungi. Hyde KD (ed). Hong Kong University Press, Hong Kong, pp 229-240.

Goh TK, Hyde KD. 1999 - Fungi on submerged wood and bamboo in the Plover Cove Reservoir, Hong Kong. Fungal Diversity 3, 57-85.

Haslam SM. 1972 - Biological flora of the British Isles no. 128, Phragmites communis Trin. Journal of Ecology 60, 585-610. http://dx.doi.org/10.2307/2258363

Ho WH, Tsui CKM, Hodgkiss IJ, Hyde KD. 1999 - Aquaticola, a new genus of Annulatascaceae from freshwater habitats. Fungal Diversity 3, 87-97.

Ho WH, Hyde KD, Hodgkiss IJ, Yanna. 2001- Fungal communities on submerged wood from streams in Brunei, Hong Kong and Malaysia. Mycological Research 105, 1492-1501. http://dx.doi.org/10.1017/S095375620100507X

Hu DM, Cai L, Chen H, Hyde KD. 2010 - Four new freshwater fungi associated with submerged wood from Southwest Asia. Sydowia 62, 191-203.

Hu DM, Liu F, Cai L. 2013 - Biodiversity of aquatic fungi in China. Mycology 4, 125-168. http://dx.doi.org/10.1080/21501203.2013.835752

Hyde KD. 1994 - Fungi from palms. XII. Three new intertidal ascomycetes from submerged palm fronds. Sydowia 46, 257-264.

Hyde KD. 1996 - Fungi from palms. XXIX. Arecophila gen. nov. (Amphisphaeriaceae, Ascomycota), with five new species and two new combinations. Nova Hedwigia 63:81100. 
Hyde KD. 2002 - Tropical Australian freshwater fungi. X. Submerisphaeria aquaticola gen. et sp. nov. Nova Hedwigia 62, 171-175.

Hyde KD, Goh TK. 1998 - Fungi on submerged wood in Lake Barrine, north Queensland, $\begin{array}{llll}\text { Australia. } & \text { Mycological } & \text { 739-749. }\end{array}$ http://dx.doi.org/10.1017/S0953756297005868

Hyde KD, Goh TK. 1999 - Fungi on submerged wood from the River Coln, England. Mycological Research 103, 1561-1574. http://dx.doi.org/10.1017/S0953756299008989

Hyde KD, Goh TK. 2003 - Adaptations for dispersal in filamentous freshwater fungi. Fungal Diversity Research Series 10, 231-258.

Hyde KD, Goh TK, Steinke TD.1998 - Fungi on submerged wood in the Palmiet River, Durban South Africa. South African Journal of Botany 64, 151-162. http://dx.doi.org/10.1016/S0254-6299(15)30860-7

Hyde KD, Jones EBG, Liu JK, Ariyawansa H, Boehm E, Boonmee S, Braun U, Chomnunti P, Crous PW, Dai DQ, Diederich P, Dissanayake A, Doilom M, Doveri F, Hongsanan S, Jayawardena R, Lawrey JD, Li YM, Liu YX, Lücking R, Monkai J, Muggia L, Nelsen MP, Pang, KL, Phookamsak R, Senanayake IC, Shearer CA, Suetrong S, Tanaka K, Thambugala KM, Wijayawardene NN, Wikee S, Wu H X, Zhang Y, Aguirre-Hudson B, Alias SA, Aptroot A, Bahkali AH, Bezerra JL, Bhat DJ, Camporesi E, Chukeatirote E, Gueidan C, Hawksworth DL, Hirayama K, Hoog SD, Kang J C, Knudsen K, Li W J, Li XH, Liu ZY, Mapook A, McKenzie EHC, Miller AN, Mortimer PE, Phillips AJL, Raja HA, Scheuer C, Schumm F, Taylor JE, Tian Q, Tibpromma S, Wanasinghe DN, Wang Y, Xu JC, Yacharoe S, Yan JY, Zhang M. 2013 - Families of dothideomycetes. Fungal Diversity 63, 1-313. http://dx.doi.org/10.1007/s13225-013-0263-4

Hyde KD, Jones EBG, Camporesi E, Mckenzie EHC, Hongsanan S, Phookamsak R, Luo ZL, Boonmee S, Li WJ, Dissanayake AJ, Jayasiri SC, Su HY, Zhao Q, Lu YZ, Wanasinghe DN, Phukhamsakda C, Norphanphoun C, Lee HB, Kytövuori I, Lin CG, Mapook A, Tanaka K, Senanayake IC, Raj KNA, Perera RH, Doilom M, Tibpromma S, Huang SK, Thambugala KM, Neta A, Zhang JF, Liu ZY, Ghosh A, Sandaruwan D, Yang J, Mafalda-Freire F, Daranagama DA, Papizadeh M, Tian Q, Wijayawardene NN, Chomnunti P, Ariyawansa HA, Ekanayaka AH, de Silva NI, Thongbai B, Cui BK, Uniyal P, Santiago ALCMA, Zeng XY, Jayawardena RS, Konta S, Abdel-Wahab MA, Hashimoto A, Zhang H, Wu H, Shang QJ, Goh TK, Dayarathne MC, Lantieri A, Liu JK, Niskanen T, Liimatainen K, Kamolhan S, Banmai S, Bulgakov TS, Nguyen TTT, Bhat DJ, Drechsler-Santos R, Buyck B, Baghela A, Das K, Reck MA, Soudi MR, Manimohan P, Stadler M, Richter C, Kirk PM, Bahkali AH, Abdel-Aziz FA, Takahashi T, Wang Y, Karunarathna SC, Lücking R, Vizzini A, Medardi G, Fazeli SA, Gibertoni TB, Wulandari NF, Duong TT, Li J, Manawasinghe IS, Bojantchev D, Ammirati JF, Bhatt RP, de Lima CLF, de Souza CAF, Wen TC, Tangthirasunun N, Dai YC, Zhou JL, Zhu L, de Oliveira RJV, Mortimer PE, Xu J, Ercole E. 2016 - Fungal diversity notes 367-490: taxonomic and phylogenetic contributions to fungal taxa. Fungal Diversity 80, 1-270. doi:10.1007/s13225-016-0373-x

Index Fungorum 2016. - $\quad$ Index Fungorum. Available from: http://www.indexfungorum.org/names/Names.asp (accessed 2 October 2016)

Ingold, CT. 1942 - Aquatic hyphomycetes of decaying alder leaves. Transactions of the British Mycological Society 25, 339-417. http://dx.doi.org/10.1016/S0007-1536(42)80001-7

Ingold, CT. 1954 - Aquatic ascomycetes: discomycetes from lakes. Transactions of the British Mycological Society 37, 1-18. http://dx.doi.org/10.1016/S0007-1536(54)80059-3

Ingold, CT. 1955 - Aquatic ascomycetes: further species from the English Lake District. Transactions of the British Mycological Society 38, 157-168. http://dx.doi.org/10.1016/S0007-1536(55)80026-5

Ito T, Yokoyama T. 1979 - Distribution of Limnoperdon incarnatum Escobar in rice paddy field soils. In: proceedings of the $23^{\text {rd }}$ Annual Meeting of the Mycological Society Japan, Ostu May 25-26 p. 75 (Abstr). 
Jones EBG, Choeyklin R. 2008 - Ecology of marine and freshwater basidiomycetes. in: Ecology of saprotrophic basidiomycetes. Boddy L, Frankland JC, van West P (eds) Academic Press, London, pp 301-324.

Jones EBG, Eaton RA. 1969 - Savoryella lignicola gen. et sp. nov. from water-cooling towers. Transactiona of the British Mycological Society 52, 161-165. http://dx.doi.org/10.1016/S0007-1536(69)80169-5

Jones EBG, Hyde KD.1988 - Methods for the study of marine fungi from the mangroves. in: Mangrove microbiology. Role of microorganisms in nutrient cycling of mangrove soils and waters. Agate AD, Subramanian CV, Vannucci M (eds) UNDP/UNESCO, New Dehli, pp 9-27.

Jones E B G, Oliver AC. 1964 - Occurrence of aquatic hyphomycetes on wood submerged in fresh and brackish water. Transactions of the British Mycological Society 47, 45-48.

Jones, EBG, Southworth D, Libkind D, Marvanová L. 2014 - Freshwater Basidiomycetes. In: Freshwater fungi. Jones EBG, Hyde KD, Pang KL (eds). Walter de Gruyter Gmbh, Germany. 73-108.

Lamore BJ, Goos RD.1978 - Wood-inhabiting fungi of a freshwater stream in Rhode Island. Mycologia 70, 1025-1034. doi:10.2307/3759135

Li GJ, Hyde KD, Zhao RL, Hongsanan S, Abdel-Aziz FA, Abdel-Wahab MA, Alvarado P, AlvesSilva G, Ammirati JF, Ariyawansa HA, Baghela A, Bahkali AH, Beug M, Bhat DJ, Dimitar Bojantchev D, Boonpratuang T, Bulgakov TS, Camporesi E, Boro MC, Ceska O, Chakraborty D, Chen JJ, Chethana KWT, Chomnunti P, Consiglio G, Cui BK, Dai DQ, Dai YC, Daranagama DA, Das K, Dayarathne MC, De Crop E, De Oliveira RJV, de Souza CAF, de Souza JI, Dentinger BTM, Dissanayake AJ, Doilom M, Drechsler-Santos ER, Ghobad- Nejhad M, Gilmore SP, Góes-Neto A, Gorczak M, Haitjema CH, Hapuarachchi KK, Hashimoto A, He MQ, Henske JK, Hirayama K, Iribarren MJ, Jayasiri SC, Jayawardena RS, Sun Jeong Jeon, Gustavo H Jerônimo, Ana L Jesus, EB Gareth Jones, Ji Chuan Kang, Karunarathna SC, Kirk PM, Konta S, Kuhnert E, Langer E, Lee HS, Lee HB, Li WJ, Li XH, Liimatainen K, Lima DX, Lin CG, Liu JK, Liu XZ, Liu ZY, Luangsaard JJ, Lücking R, Lumbsch HT, Lumyong S, Leaño EM, Marano AV, Matsumura M, McKenzie EHC, Mongkolsamrit S, Mortimer PE, Nguyen TTT, Niskanen T, Norphanphoun C, O’Malley MA, Parnmen S, Pawłowska J, Perera RH, Phookamsak R, Phukhamsakda C, Pires-Zottarelli CLA, Raspé O, Reck MA, Rocha SCO, de Santiago ALCMA, Senanayake IC, Setti L, Shang QJ, Singh SK, Sir EB, Solomon KV, Song J, Srikitikulchai P, Stadler M, Suetrong S, Takahashi H, Takahashi T, Tanaka K, Tang LP, Thambugala KM, Thanakitpipattana D, Theodorou MK, Thongbai B, Thummarukcharoen T, Tian Q, Tibpromma S, Verbeken A, Vizzini A, Vlasák J, Voigt K, Wanasinghe DN, Wang Y, Weerakoon G, Wen HA, Wen TC, Wijayawardene NN, Wongkanoun S, Wrzosek M, Xiao YP, Xu JC, Yan JY, Yang J, Yang SD, Hu Y, Zhang JF, Zhao J, Zhou LW, Peršoh D, Phillips AJL, Maharachchikumbura SSN. 2016 - Fungal diversity notes 253-366: taxonomic and phylogenetic contributions to fungal taxa. Fungal Diversity 78, 1-237. http://dx.doi.org/10.1007/s13225-016-0366-9

Liu JK, Hyde KD, Jones EBG, Ariyawansa HA, Bhat DJ, Boonmee S, Maharachchikumbura SSN, Mckenzie EHC, Phookamsak R, Phukhamsakda C, Shenoy BD, Abdel-Wahab MA, Buyck B, Chen J, Chethana KWT, Singtripop C, Dai DQ, Dai YC, Daranagama DA, Dissanayake AJ, Doilom M, D'souza MJ, Fan XL, Goonasekara ID, Hirayama K, Hongsanan S, Jayasiri SC, Jayawardena RS, Karunarathna SC, Li WJ, Mapook A, Norphanphoun C, Pang KL, Perera RH, Peršoh D, Pinruan U, Senanayake IC, Somrithipol S, Suetrong S, Tanaka K, Thambugala KM, Tian Q, Tibpromma S, Udayanga D, Wijayawardene NN, Wanasinghe D, Wisitrassameewong K, Zeng XY, Abdel-Aziz FA, Adamčík S, Bahkali AH, Boonyuen N, Bulgakov T, Callac P, Chomnunti P, Greiner K, Hashimoto A, Hofstetter V, Kang JC, Lewis D, Li XH, Liu XX, Liu ZY, Matsumura M, Mortimer PE, Rambold G, Randrianjohany E, Sato G, Sri-Indrasutdhi V, Tian CM, Verbeken A, Brackel WV, Wang Y, Wen TC, Xu JC, 
Yan JY, Zhao RL, Camporesi E. 2015 - Fungal Diversity Notes 1-110: Taxonomic and phylogenetic contributions to fungal species. Fungal Diversity 72, 1-197. http://dx.doi.org/10.1007/s13225-015-0324-y

Luo J, Yin JF, Cai L, Zhang KQ, Hyde KD. 2004 - Freshwater fungi in Lake Dianchi, a heavily polluted lake in Yunnan, China. Fungal Diversity 16, 93-112.

Maharachchikumbura SSN, Hyde KD, Jones EBG, McKenzie EHC, Huang SK, Abdel-Wahab MA, Daranagama DA, Dayarathne M, D'Souyza KJ, Goonasekara ID, Hongsana S, Jayawardena RS, Kirk PM, Konta RH, Liu JK, Norphanphoun C, Pang KL, Perera RH, Senanayake I.C., Shang, Q., Shenoy, B.D., Xiao, Y., Bahkali, A.H., Kang, J., Somrothipol, S. \& Sueterong, S. .2015- Towards a natural classification and backbone tree for Sordariomycetes. Fungal Diversity 72, 199-301. http://dx.doi.org/10.1007/s13225-015-0331-z

Maharachchikumbura SSN, Hyde KD, Jones EBG, McKenzie EHC, Bhat DJ, Dayarathne MC, Huang SK, Norphanphoun C, Senanayake IC, Perera RH, Shang QJ, Xiao YP, D'souza MJ, Hongsanan S, Jayawardena RS, Daranagama DA, Konta S, Goonasekara ID, Zhuang WY, Jeewon R, Phillips AJL, Abdel-Wahab MA, Al-Sadi AM, Bahkali AH, Boonmee S, Boonyuen N, Cheewangkoon R, Dissanayake AJ, Kang JC, Li QR, Liu JK, Liu XZ, Liu ZY, Luangsa-ard JJ, Pang KL, Phookamsak R, Promputtha I, Suetrong S, Stadler M, Wen TC, Wijayawardene NN. 2016 - Families of Sordariomycetes. Fungal Diversity 79, 1-317. http://dx.doi.org/10.1007/s13225-016-0369-6

Marvanova L, Suberkropp K. 1990 - Camptobasidium hydrophilum and its anamorph crucella Subtilis: a new heterobasidiomycete from streams. Mycologia 82, 208-217. http://dx.doi.org/10.2307/3759849

Nawawi A, Webster J. 1982 - Sistotrema hamatum sp. nov., the teleomorph of Ingoldiella hamata. Transactions of the British Mycological Society 78, 287-291. http://dx.doi.org/10.1016/S0007-1536(82)80012-0

Poon MOK, Hyde KD. 1998 - Biodiversity of intertidal estuarine fungi on Phragmites at Mai Po marshes, Hong Kong. Botanica Marina 41, 141-155. http://dx.doi.org/10.1515/botm.1998.41.1-6.285

Raja HA, Miller AN, Shearer CA. 2012 - Freshwater ascomycetes: natipusillaceae, a new family of tropical fungi, including Natipusilla bellaspora sp. nov. from the Peruvian Amazon. Mycologia 104, 569-573. http://dx.doi.org/10.3852/11-150

Ryckegem GV, Gessner MO, Verbeken A. 2007 - Fungi on leaf blades of Phragmites australis in a brackish tidal marsh: Diversity, succession, and leaf decomposition. Microbial Ecology 53, 600-611. http://dx.doi.org/10.1007/s00248-006-9132-y

Ryckegem GV, Verbeken A. 2005 - Fungal ecology and succession on Phragmites australis in a brackish tidal marsh. II. Stems. Fungal Diversity 20, 209-233.

Shearer CA.1993 - The freshwater ascomycetes. Nova Hedwigia 56, 1-33.

Shearer CA, Crane JL. 1986 - Illinios fungi XII Fungi and Myxomycetes from wood and leaves submerged in a freshwater swamp. Mycotaxon 25, 527-538.

Shearer CA, Raja HA. 2016 - Freshwater Ascomycetes and their anamorphs. http://fungi.life.illinois.edu/. Accessed 2 October 2016.

Shearer CA,Von Bodman SB. 1983 - Patterns of occurrence of ascomycetes associated with decomposing twigs in a Midwestern stream. Mycologia 75, 518-530. http://dx.doi.org/10.2307/3792693

Sivichai S, Jones EBG. 2004 - Stauriella gen. nov., proposed for a new lignicolous basidiomycetous anamorph from freshwater in Thailand. Sydowia 56, 131-136.

Su HY, Udayanga D, Luo ZL, Yang J, Zhou DQ, Hyde KD. 2015 - Backbone tree for Chaetothyriales and phylogenetic placement of Minimelanolocus in Chaetothyriales with four new species of Minimelanolocus from aquatic habitats. Fungal Biology 119, 1046-62. 
http://doi: 10.1016/j.funbio.2015.08.005

Sridhar KR, Bärlocher F. 2000 - Initial colonization, nutrient supply, and fungal activity on leaves decaying in streams. Applied and Environmental Microbiology 66, 1114-1119. http://dx.doi.org/10.1128/AEM.66.3.1114-1119.2000

Swe A, Jeewon R, Pointing SB, Hyde KD. 2009 - Diversity and abundance of nematode-trapping fungi from decaying litter in terrestrial, freshwater and mangrove habitats. Biodiversity and Conservation 18, 1695-1714. http://dx.doi.org/10.1007/s10531-008-9553-7

Taligoola TK, Apinis AE, Chester CGC. 1972 - Microfungi colonizing collapsed aerial parts of Phragmites communis Trin. in water. Nova Hedwigia 23, 465-472.

Tsui CKM, Hyde KD, Hodgkiss IJ. 2000 - Biodiversity of fungi on submerged wood in Hong Kong streams. Aquatic Microbial Ecology 21, 289-298. http://dx.doi.org/10.3354/ame021289

Tsui CKM, Hyde KD, Hodgkiss IJ. 2001 - Longitudinal and temporal distribution of ascomycetes and dematacious hyphomycetes on submerged wood in the Lam Tsuen River. Journal of the North American Benthological Society 20, 601-615. http://dx.doi.org/10.2307/1468086

Tubaki K. 1977 - Brackish water fungi and their relationship to marine fungi. In: proceeding of the $2^{\text {nd }}$ mycological congress, Tampa, Forida, August 27-September 3, p 681.

Vijaykrishna D, Hyde KD. 2006 - Inter and intra stream variation of lignicolous freshwater fungi in tropical Australia. Fungal Diversity 21, 203-224.

Webster J. 1959 - Nectria lugdunensis sp. nov., the perfect state of Heliscus lugdunensisi. Transactions of the British Mycological Society 42, 322-327. http://dx.doi.org/10.1016/S0007-1536(56)80040-5

Weiss EA. 1979 - some indigenous plants used domestically by east African coastal fishermen. Economic Botany 33, 35-51. http://dx.doi.org/10.1007/BF02858210

Wijayawardene NN, Crous PW, Kirk PM, Hawksworth DL, Boonmee S, Braun U, Dai DQ, D'souza MJ, Diederich P, Dissanayake A, Doilom M, Hongsanan S, Jones EBG, Groenewald JZ, Jayawardena R, Lawrey JD, Liu JK, Lücking R, Madrid H, Manamgoda DS, Muggia L, Nelsen MP, Phookamsak R, Suetrong S, Tanaka K, Thambugala KM, Wanasinghe DN, Wikee S, Zhang Y, Aptroot A, Ariyawansa HA, Bahkali AH, Bhat DJ, Gueidan C, Chomnunti P, Hoog GSD, Knudsen K, Li WJ, McKenzie EHC, Miller AN, Phillips AJL, Piątek M, Raja HA, Shivas RS, Slippers B, Taylor JE, Tian Q, Wang Y, Woudenberg JHC, Cai L, Jaklitsch WM, Hyde KD. 2014 - Naming and outline of Dothideomycetes 2014. Fungal Diversity 69:1-55. http://dx.doi.org/10.1007/s13225-0140309-2

Wong MKM, Goh TK, Hodgkiss IJ, Hyde KD, Ranghoo VM, Tsui CKM, Ho WH, Wong SW, Yuen TK. 1998 - Role of fungi in freshwater ecosystems. Biodiversity and Conservation 7, 1187-1206. http://dx.doi.org/10.1023/A:1008883716975

Wong MKM, Hyde KD. 2001 - Diversity of fungi on six species of Gramineae and one species of Cyperaceae in Hong Kong. Mycological Research 105, 1485-1491. http://dx.doi.org/10.1017/S0953756201004695

Zhang H, Hyde KD, Abdel-Wahab MA, Abdel-Aziz FA, Hirab A, Ariyawabsam Thida W, Ko Ko, Zhao EL, Alias SA, Ali H. Bahkali and Dequn Zhou. 2013 - A modern concept for Helicascus with a Pleurophomopsis-like asexual state. Sydowia 65, 147-166. 